\title{
Interrelationships between feeding, food deprivation and swimming performance in juvenile grass carp
}

\author{
Lu Cai $^{1,2}$, Min Fang ${ }^{1,2}$, David Johnson ${ }^{2,3}$, Shaoming Lin ${ }^{1}$, Zhiying Tu ${ }^{1,2}$, \\ Guoyong Liu ${ }^{1,2}$, Yingping Huang ${ }^{1,2, *}$ \\ ${ }^{1}$ Collaborative Innovation Center for Geo-Hazards and Eco-Environment in Three Gorges Area, Hubei Province, \\ Yichang 443002, PR China \\ ${ }^{2}$ Engineering Research Center of Eco-environment in Three Gorges Reservoir Region, Ministry of Education, \\ China Three Gorges University, Yichang 443002, PR China \\ ${ }^{3}$ School of Natural Sciences and Mathematics, Ferrum College, Ferrum, Virginia 24088, USA
}

\begin{abstract}
The present study investigated the interrelationships between feeding, food deprivation and swimming performance in juvenile grass carp Ctenopharynodon idellus. Oxygen consumption, as a function of swimming speed, was determined by fitting data to a power function. Speed exponents from oxygen consumption functions were 1.46, 1.23 and 1.91 with time after feeding of $6 \mathrm{~h}, 2 \mathrm{~d}$ and $2 \mathrm{wk}$, respectively, which indicated that swimming efficiency increased after digestion was complete and decreased with extended food deprivation. Excess post-exercise oxygen consumption (EPOC) increased slightly with time after feeding, and recovery time varied between 1 and $1.5 \mathrm{~h}$ after fatigue. The contribution of anaerobic metabolism began at swimming speeds 28.3 to $40.2 \%$ of critical swimming speed ( $\left.U_{\text {crit }}\right)$ and increased with time after feeding. Both optimal swimming speed and critical swimming speed decreased with time after feeding. The metabolic scope of grass carp decreased for at least $6 \mathrm{~h}$ after feeding $\left(384 \mathrm{mg} \mathrm{O}_{2} \mathrm{~kg}^{-1} \mathrm{~h}^{-1}\right)$. It nearly doubled after $2 \mathrm{~d}\left(727 \mathrm{mg} \mathrm{O} \mathrm{kg}^{-1} \mathrm{~h}^{-1}\right)$ and then declined after $2 \mathrm{wk}$ throughout the duration of food deprivation (420 $\mathrm{mg} \mathrm{O}_{2} \mathrm{~kg}^{-1} \mathrm{~h}^{-1}$ ). In conclusion, feeding and food deprivation affected swimming efficiency, metabolism (both aerobic and anaerobic) and swimming capability, with only slight effects on EPOC and recovery time. The results of the present study provide information which will assist in the design of fish ladders and resting pools and thus support fish migration and conservation of biodiversity.
\end{abstract}

KEY WORDS: Grass carp · Feeding-swimming interaction $\cdot$ Critical swimming speed $\cdot$ Aerobic respiration · Anaerobic respiration · Fatigue recovery

\section{INTRODUCTION}

Hydraulic engineering is thriving in China, and many dams are under construction. The Ministry of Water Resources (2011) reported that 87873 dams were operating in China at the end of 2010. Dams effectively control flooding and bring large economic benefits; however, they also produce environmental impacts such as interrupting fish migration. The con- struction of fish ladders is an engineering approach for mitigating impacts on fish migration. Nonetheless, an effective design requires knowledge of fish biology (Yagci 2010), specifically swimming performance, which includes swimming behavior and capability as well as the metabolic changes associated with swimming (Ohlberger et al. 2007, Tu et al. 2011).

Grass carp Ctenopharynodon idellus Valenciennes, 1844 is a large cyprinid species found primarily in 
China, with a native range from northern Vietnam to the Amur River on the Russia-China border. The fish resides in large, turbid rivers and associated floodplain lakes and can tolerate a wide range of temperatures (Cudmore \& Mandrak 2004). They are commercially valuable and used internationally for aquatic weed control. The juvenile carp grows rapidly and migration to food resources is important for survival. Grass carp thrive in freshwaters rich in vegetation given that their daily consumption can amount to up to 3 times the body mass of the fish (Cudmore \& Mandrak 2004).

While abundant research has been carried out on the nutritional requirements and biochemistry of the grass carp (Chen et al. 2012, Koprucu \& Sertel 2012, Wang et al. 2012), little has been reported on swimming performance and the relationship between feeding and swimming. This study investigated swimming performance, including swimming capability and metabolic response to swimming. Stepped velocity tests, using a Steffensen-type swimming respirometer, were used to study the interrelationships between feeding, food deprivation and swimming performance.

\section{MATERIALS AND METHODS}

\section{Test fish, acclimation and diet}

Juvenile grass carp were obtained from an aquaculture farm in Yichang, China $\left(30^{\circ} 56^{\prime} \mathrm{N}, 111^{\circ} 15^{\prime} \mathrm{E}\right)$. The fish were divided into 3 groups of 8 after arriving in the laboratory, where they were acclimated for $3 \mathrm{wk}$ in tanks filled with de-chlorinated, fully-aerated tap water with a natural photoperiod. The water temperature was kept at $20 \pm 0.5^{\circ} \mathrm{C}$ using aquarium heaters. Fish were fed to satiation daily with an appropriate compound food ( $\geq 45 \%$ crude protein, $\geq 10 \%$ fat, $\geq 3 \%$ crude fiber and $\geq 17 \%$ ash). Morphological parameters were measured with a ruler and an electronic balance (Table 1).

After the acclimation period, feeding was interrupted for 6 h (Group 1), 2 d (Group 2) or 2 wk (Group 3). These times were selected based on previous reports indicating that (1) metabolic rate increases significantly up to $12 \mathrm{~h}$ after feeding (McKenzie et al. 2003, Li et al. 2012), (2) complete digestion requires $\sim 2 \mathrm{~d}$ ( Tu et al. 2011, 2012, Li et al. 2012), and (3) fish are strongly affected by 2 wk of food deprivation (Bilton \& Robins 1973, Agius \& Roberts 1981, Li et al. 2012).

\section{Respirometer}

Testing was conducted in a 141 sealed swimming respirometer (Steffensen design) with a 4.51 swimming chamber $(35.5$ length $\times 11.0$ width $\times 11.5 \mathrm{~cm}$ height). The respirometer was submerged in a $55.7 \mathrm{l}$ tank (84.0 length $\times 39.9$ width $\times 17.0 \mathrm{~cm}$ height) (Fig. 1). Components of the respirometer included a motor, transducer, propeller, multi-aperture rectifier plate (Lucite) and a wire grid (Cai et al. 2013). The transducer controls the voltage applied to the motor, allowing the propeller speed and flow velocity to be adjusted. The rectifier plate was placed upstream of the chamber to prevent turbulence and ensure laminar flow in the chamber. The grid prevented the test fish from being swept from the chamber. A submersible pump was used to exchange water in the respirometer. Normal respirometer operating assumptions were made: (1) Swimming speed $(U)$ of the fish equals water flow speed, as measured with an acoustic Doppler velocity meter (Nortek) and (2) fish oxygen consumption is calculated based on the change in dissolved oxygen (DO, $\mathrm{mg} \mathrm{l}^{-1}$ ), measured by a probe (Hach HQ30d).

\section{Stepped velocity tests and measurement of oxygen consumption}

Stepped velocity tests were carried out in order to calculate the critical swimming speed $\left(U_{\text {crit }}\right)$ and oxygen consumption rate $\left(\mathrm{MO}_{2}\right)$ of the fish; each fish in each group $(n=8)$ was tested once. Body length of the fish was measured before the test began and fish were allowed to adapt to experimental conditions at 0.3 body lengths (BL) $\mathrm{s}^{-1}$ for $2 \mathrm{~h}$ (Jain et al. 1997).

Table 1. Ctenopharynodon idellus. Morphological parameters (mean $\pm \mathrm{SE}$ ) of grass carp in 3 experimental groups $(n=8)$ before starvation treatments. There were no significant differences among groups for any morphological parameter ( $p>0.05$ ). Condition factor $=100 \mathrm{~m} / \mathrm{LF}_{\mathrm{F}}^{3}$

\begin{tabular}{|lcccccc|}
\hline $\begin{array}{c}\text { Group } \\
\text { Starva- } \\
\text { tion }\end{array}$ & $\begin{array}{c}\text { Body length } \\
\left(L_{\mathrm{B}}, \mathrm{cm}\right)\end{array}$ & $\begin{array}{c}\text { Fork length } \\
\left(L_{\mathrm{F}}, \mathrm{cm}\right)\end{array}$ & $\begin{array}{c}\text { Total length } \\
\left(L_{\mathrm{T}}, \mathrm{cm}\right)\end{array}$ & $\begin{array}{c}\text { Body mass } \\
(m, \mathrm{~g})\end{array}$ & $\begin{array}{c}\text { Condition } \\
\text { factor }\end{array}$ \\
\hline 1 & $6 \mathrm{~h}$ & $11.02 \pm 0.32$ & $12.73 \pm 0.41$ & $14.05 \pm 0.35$ & $28.89 \pm 2.42$ & $1.40 \pm 0.03$ \\
2 & $2 \mathrm{~d}$ & $10.59 \pm 0.30$ & $12.45 \pm 0.35$ & $13.12 \pm 0.34$ & $27.33 \pm 1.78$ & $1.42 \pm 0.03$ \\
3 & $2 \mathrm{wk}$ & $11.08 \pm 0.36$ & $12.71 \pm 0.39$ & $14.12 \pm 0.41$ & $28.98 \pm 2.36$ & $1.41 \pm 0.04$ \\
\hline
\end{tabular}




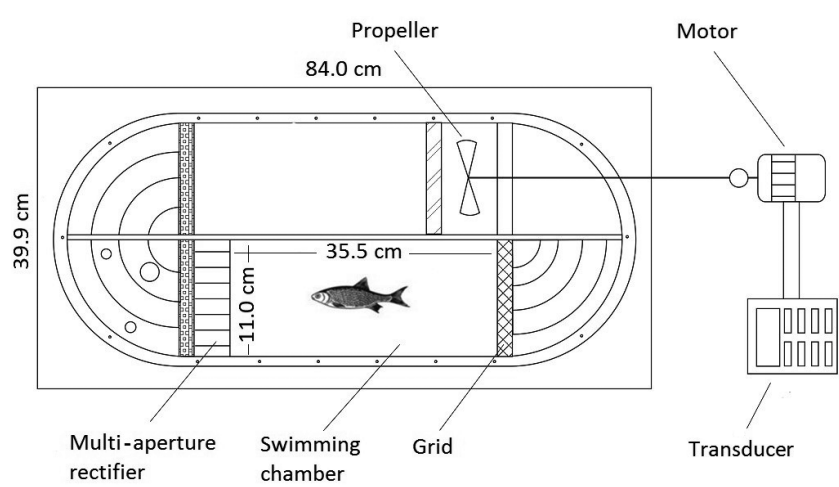

Fig. 1. Respirometer used to assess swimming performance of fish

During the stepped velocity test, flow speed was held constant at $0.3 \mathrm{BL} \mathrm{s}^{-1}$ for $30 \mathrm{~min}$. Then, beginning at $1 \mathrm{BL} \mathrm{s}^{-1}$, flow speed was increased by $1 \mathrm{BL} \mathrm{s}^{-1}$ at 30 min intervals $(20$ min DO measurement, 5 min flushing and 5 min equilibration) until exhaustion (test fish ceased swimming and rested against the grid). Once the fish was exhausted, flow speed was decreased to $0.3 \mathrm{BL} \mathrm{s}^{-1}$ for $1.5 \mathrm{~h}$. During recovery, DO was measured and recorded at 10 min intervals. When the test was completed, fork length, total length and body mass were re-measured.

$U_{\text {crit }}$ was calculated from the stepped velocity test as described by Brett (1964). The $\mathrm{MO}_{2}$ was obtained using the equation:

$$
\mathrm{MO}_{2}=\left[d(\mathrm{DO}) / d t-d(\mathrm{DO})^{\prime} / d t\right] \times V / m
$$

where $V(\mathrm{l})$ is volume of the swimming respirometer, $m(\mathrm{~kg})$ is mass of the carp, $d(\mathrm{DO}) / d t\left(\mathrm{mg} \mathrm{O}_{2} \mathrm{l}^{-1} \mathrm{~h}^{-1}\right)$ is the change in dissolved oxygen, and $d(\mathrm{DO})^{\prime} / d t(\mathrm{mg}$ $\mathrm{O}_{2} \mathrm{l}^{-1} \mathrm{~h}^{-1}$ ) is the mean control value (change in dissolved oxygen with no fish), which was measured 3 times ( $12 \mathrm{~h}$ per time) before the stepped velocity tests. Routine oxygen consumption rate (RMR) is the $\mathrm{MO}_{2}$ at $0.3 \mathrm{BL} \mathrm{s}^{-1}$. Maximum oxygen consumption rate (MMR) is the maximum value of $\mathrm{MO}_{2}$ during the stepped velocity test. The metabolic scope (MS) is the difference between MMR and RMR and is related to the energy potentially available for swimming (Tu et al. 2012).

\section{Data analysis}

All values are reported as mean $\pm \mathrm{SE}$, and the level of statistical significance was set at $p<0.05$. Statistical comparisons were made using parametric analysis of variance (ANOVA, Fisher LSD). Origin software (version 8.1) was used for analysis and graphing.
During the swimming period, variation of $\mathrm{MO}_{2}$ with $U$ was obtained by fitting the data to the function:

$$
\mathrm{MO}_{2}=a+b U^{c}
$$

where $a, b$ and $c$ are constants. During the recovery period, variation of $\mathrm{MO}_{2}$ with time $(t)$ was obtained by fitting the data to the function:

$$
\mathrm{MO}_{2}=a+b e^{c t}
$$

where $a, b$ and $c$ are constants.

Excess post-exercise oxygen consumption (EPOC) is the difference between aerobic oxygen consumption and routine oxygen consumption during recovery from exhaustion. Total oxygen consumption was calculated by adding EPOC to aerobic oxygen consumption, assuming that EPOC is the oxygen consumed to recover from anaerobic metabolism (Brett 1964). Total oxygen consumption was obtained using the iterative method by Lee et al. (2003a). Iteration was continued until the total consumption matched oxygen consumption before and after fatigue. On the final iteration, the oxygen consumed during recovery, EPOC, and the area between the $\mathrm{MO}_{2}$ curve and the broken line differed $<1 \%$. The broken line was then used to estimate the time at which anaerobic respiration began. The maximum aerobic speed $\left(U_{\mathrm{a}}\right)$, the beginning of anaerobic respiration, is the maximum swimming speed using aerobic respiration only.

Cost of transport (COT) is the energy expended for moving $1 \mathrm{~kg}$ of body mass by $1 \mathrm{~m}$ using an oxycaloric value of $14.1 \mathrm{~J} \mathrm{mg}^{-1} \mathrm{O}_{2}$. The following function was used to find the relationship between COT and $U$ :

$$
\mathrm{COT}=a U^{-1}+b U^{\mathrm{c}-1}
$$

where $a, b$ and $c$ are constants. Optimal swimming speed $\left(U_{\text {opt }}\right)$ is the swimming speed with minimum COT.

\section{RESULTS}

\section{Condition factor, RMR, MMR and MS}

After starvation, before the swimming tests, there was no change in condition factor $(\mathrm{CF})$ in both Group 1 and Group 2. The CF of Group 3 declined significantly after starvation (Table 2). The results for the parameters based on oxygen consumption after the swimming tests are given in Table 2. RMR of Groups 1 and 2 were significantly different, but the RMR of Group 3 did not differ significantly from the other 2 groups. MMR of Group 2 was significantly higher than both Group 1 and Group 3. MS increased and then decreased with starvation period (Table 2). 
Table 2. Ctenopharynodon idellus. Condition factor and metabolic parameters (mean \pm SE) for grass carp in 3 experimental groups. Routine oxygen consumption rate $(\mathrm{RMR})=$ oxygen consumption rate $\left(\mathrm{MO}_{2}\right)$ at 0.3 BL (body lengths) $\mathrm{s}^{-1}$. Maximum oxygen consumption rate $(\mathrm{MMR})=$ maximum value of $\mathrm{MO}_{2}$ during the stepped velocity test. Metabolic scope $(\mathrm{MS})=\mathrm{MMR}-$ RMR. Excess post-exercise oxygen consumption $(\mathrm{EPOC})=$ difference between aerobic oxygen consumption and routine oxygen consumption during recovery from exhaustion. Superscript letters: significant differences $(p<0.05)$ between groups. If 2 groups have the same letter, there is no significant difference between them

\begin{tabular}{|lcccccc|}
\hline Group & Starvation & $\begin{array}{c}\text { Condition } \\
\text { factor }\end{array}$ & $\begin{array}{c}\mathrm{RMR} \\
\left(\mathrm{mg} \mathrm{O}_{2} \mathrm{~kg}^{-1} \mathrm{~h}^{-1}\right)\end{array}$ & $\begin{array}{c}\mathrm{MMR} \\
\left(\mathrm{mg} \mathrm{O}_{2} \mathrm{~kg}^{-1} \mathrm{~h}^{-1}\right)\end{array}$ & $\begin{array}{c}\text { Mean MS } \\
\left(\mathrm{mg} \mathrm{O}_{2} \mathrm{~kg}^{-1} \mathrm{~h}^{-1}\right)\end{array}$ & $\begin{array}{c}\mathrm{EPOC} \\
\left(\mathrm{mg} \mathrm{O}_{2} \mathrm{~kg}^{-1}\right)\end{array}$ \\
\hline 1 & $6 \mathrm{~h}$ & $1.42 \pm 0.03^{\mathrm{a}}$ & $321.25 \pm 40.19^{\mathrm{a}}$ & $704.98 \pm 44.80^{\mathrm{a}}$ & 384 & 106 \\
2 & $2 \mathrm{~d}$ & $1.41 \pm 0.03^{\mathrm{a}}$ & $199.49 \pm 30.31^{\mathrm{b}}$ & $926.07 \pm 66.98^{\mathrm{b}}$ & 727 & 110 \\
3 & $2 \mathrm{wk}$ & $1.30 \pm 0.04^{\mathrm{b}}$ & $218.99 \pm 36.87^{\mathrm{a}, \mathrm{b}}$ & $638.13 \pm 78.14^{\mathrm{a}}$ & 420 & 113 \\
\hline
\end{tabular}
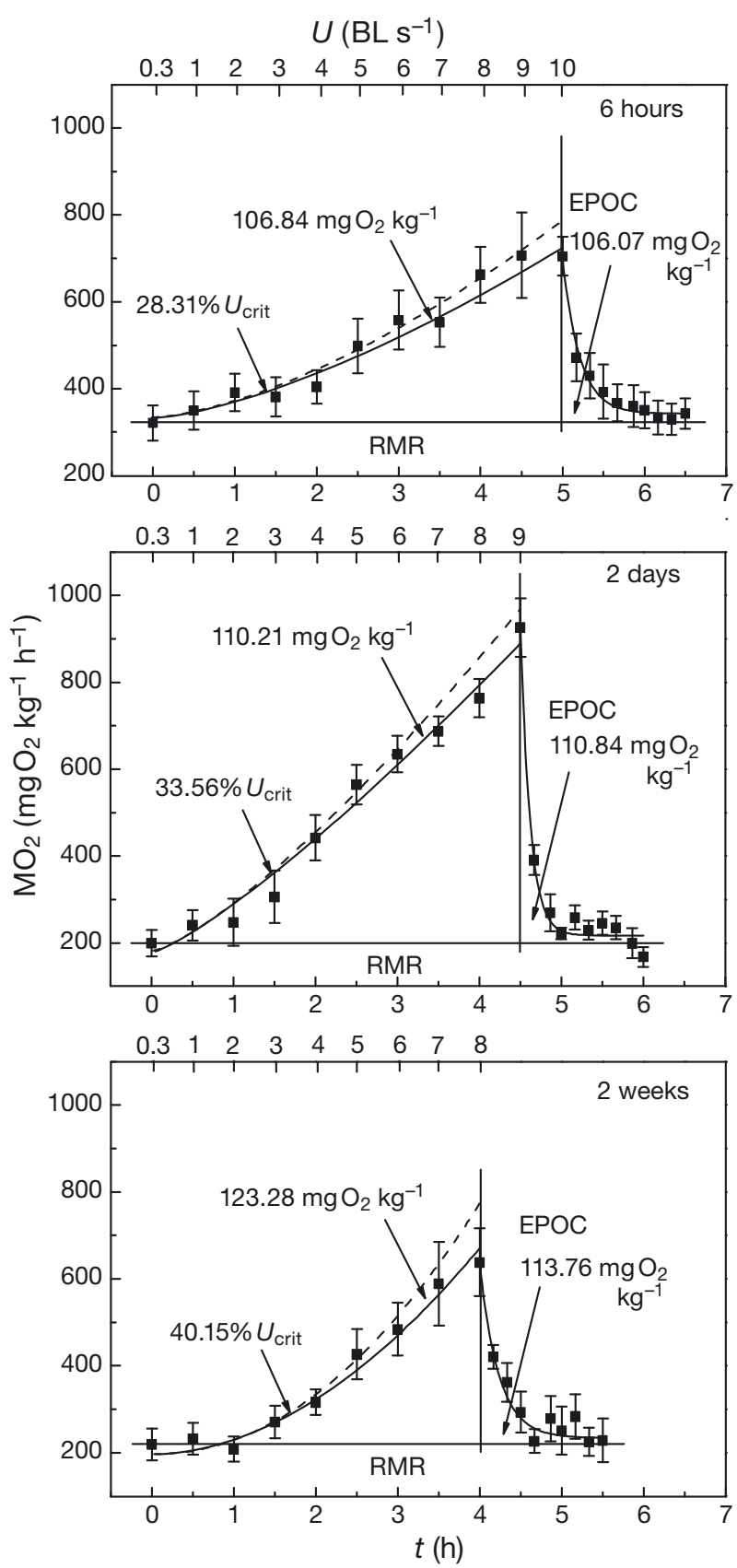

\section{$U_{\text {crit }}$ and swimming efficiency}

Further analysis of the results are illustrated in Fig. 2 and Table 3. During the swimming period, the fit $\left(R^{2}\right)$ in Eq. (2) for Groups 1, 2 and 3 were 0.950, 0.976 and 0.953 , respectively. $U_{\text {crit }}$ decreased with starvation period, and the difference between Group 1 and Group 3 was significant. The speed exponent (c) is inversely related to swimming efficiency and increased from Group 1 to Group 2 and decreased significantly in Group 3.

\section{EPOC and $\% U_{\text {crit }}$}

During the recovery period, $R^{2}$ in Eq. (3) for all groups was 0.999. EPOC was calculated by computing the area under the $\mathrm{MO}_{2}$ curve after fatigue, and only a small difference among groups was found. Recovery time, which is the time from fatigue until $\mathrm{MO}_{2}$ returns to RMR, varied from 1 to $1.5 \mathrm{~h}$ (Fig. 2). Using the value of $U$ that corresponds to the onset time of anaerobic respiration, $U_{\mathrm{a}}$ was calculated; the values increased with starvation period (Table 3 ).

\section{COT and $U_{\text {opt }}$}

The results presented in Fig. 3 and Table 3 were used to determine $U_{\text {opt }}$ for grass carp. COT decreased

Fig. 2. Ctenopharynodon idellus. Oxygen consumption rate $\left(\mathrm{MO}_{2}\right)$ over time for 3 experimental treatments. Ascending (aerobic) curve: aerobic respiration before fatigue; descending (recovery) curve: rate of oxygen consumption during fatigue recovery. Broken line (total oxygen consumption) indicates the total metabolic rate $\left(\mathrm{MO}_{2}\right.$ equivalent) obtained by adding aerobic and anaerobic metabolism. $U_{\text {crit }}$ : critical swimming speed. EPOC: excess post-exercise oxygen consumption. RMR: routine oxygen consumption rate 
Table 3. Ctenopharynodon idellus. Swimming performance of grass carp in 3 experimental groups. Speed exponent is the value of $c$ in Eq. $2\left(\mathrm{MO}_{2}=a+b U^{c}\right) ; U_{\text {crit }}=$ critical swimming speed (mean $\pm \mathrm{SE}) ; U_{\mathrm{a}}=$ maximum aerobic speed, the beginning of anaerobic respiration, is the swimming speed using aerobic respiration only; $U_{\text {opt }}=$ optimal swimming speed, with minimum cost of transport. Superscript letters: significant differences $(p<0.05)$ between groups of different letters. BL: body lengths

\begin{tabular}{|lccccc|}
\hline $\begin{array}{c}\text { Group } \\
\text { Starva- } \\
\text { tion }\end{array}$ & $C$ & $\begin{array}{c}U_{\text {crit }} \\
\left(\mathrm{BL} \mathrm{s}^{-1}\right)\end{array}$ & $\begin{array}{c}U_{\mathrm{a}} \\
\left(\% U_{\text {crit }}\right)\end{array}$ & $\begin{array}{c}U_{\text {opt }} \\
\left(\mathrm{BL} \mathrm{s}^{-1}\right)\end{array}$ \\
\hline 1 & $6 \mathrm{~h}$ & 1.46 & $9.89 \pm 0.54^{\mathrm{a}}$ & 28.3 & 9.9 \\
2 & $2 \mathrm{~d}$ & 1.23 & $8.94 \pm 0.41^{\mathrm{a}, \mathrm{b}}$ & 33.6 & 7.3 \\
3 & $2 \mathrm{wk}$ & 1.91 & $7.97 \pm 0.52^{\mathrm{b}}$ & 40.2 & 4.6 \\
\hline
\end{tabular}

dramatically as swimming speed increased from 1 to $3 \mathrm{BL} \mathrm{s}^{-1}$, but at higher speeds the change in COT with $U$ was smaller and depended on starvation period. For Group 1, COT decreased continually with swimming speed and $U_{\text {opt }}$ equaled 10.0 BL s${ }^{-1}$. There was a weak deflection point for Group 2, indicating $U_{\text {opt }}=7.3 \mathrm{BL} \mathrm{s}^{-1}$. Group 3 data had a stronger inflection point, indicating $U_{\text {opt }}=4.6 \mathrm{BL} \mathrm{s}^{-1}$.

With food deprivation, both EPOC and the onset of anaerobic metabolism were directly proportional to the log of time after feeding $\left(R^{2}=0.972\right.$ and 0.986 , $\mathrm{p}=0.076$ and 0.053, respectively) (Fig. 4). $U_{\text {opt }}$ is inversely and linearly related to the log of time after feeding $\left(R^{2}=0.999, \mathrm{p}=0.076\right)$ (Fig. 5).

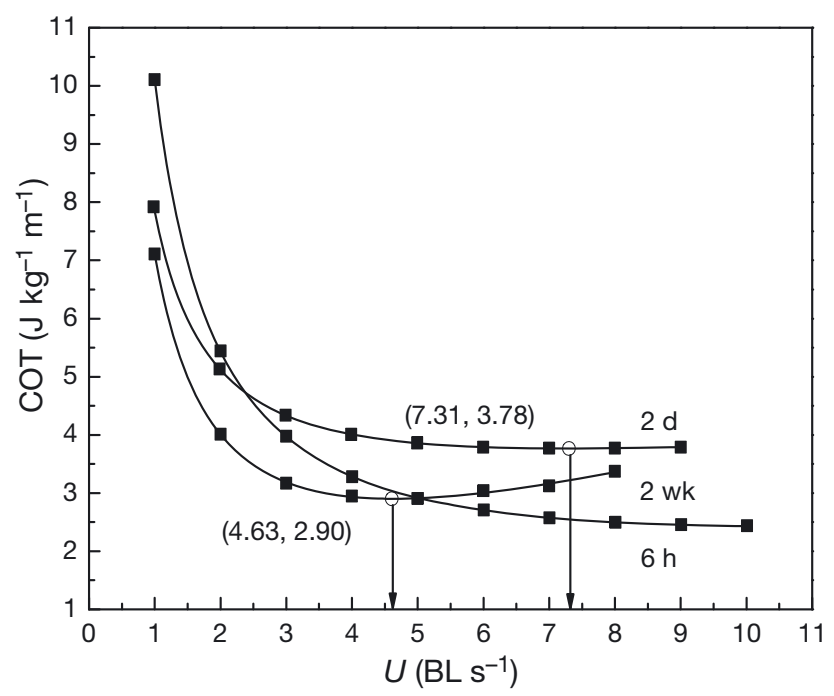

Fig. 3. Ctenopharynodon idellus. Variation of cost of transport (COT) with swimming speed $\left(U\right.$; body lengths $\left.[B L] \mathrm{s}^{-1}\right)$. (O) inflection points $(7.31,3.78),(4.63,2.90)$. Group 1, Group 2 and Group 3 fish were tested after starvation periods of $6 \mathrm{~h}, 2 \mathrm{~d}$, and $2 \mathrm{wk}$, respectively

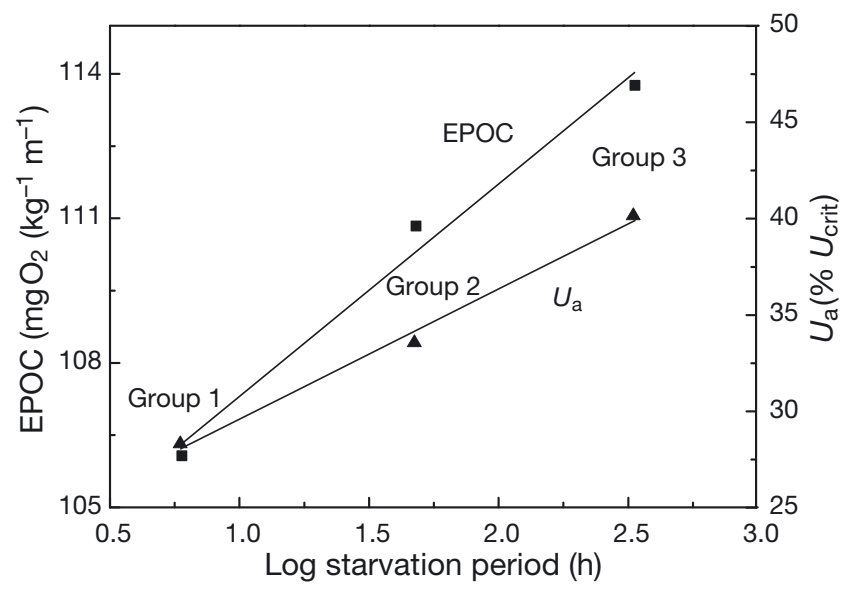

Fig. 4. Ctenopharynodon idellus. Variation of excess postexercise oxygen consumption (EPOC) and onset of anaerobic swimming $\left(U_{\mathrm{a}}\right)$ with starvation period. See Fig. 3 for details on Groups. $U_{\text {crit }}$ : critical swimming speed

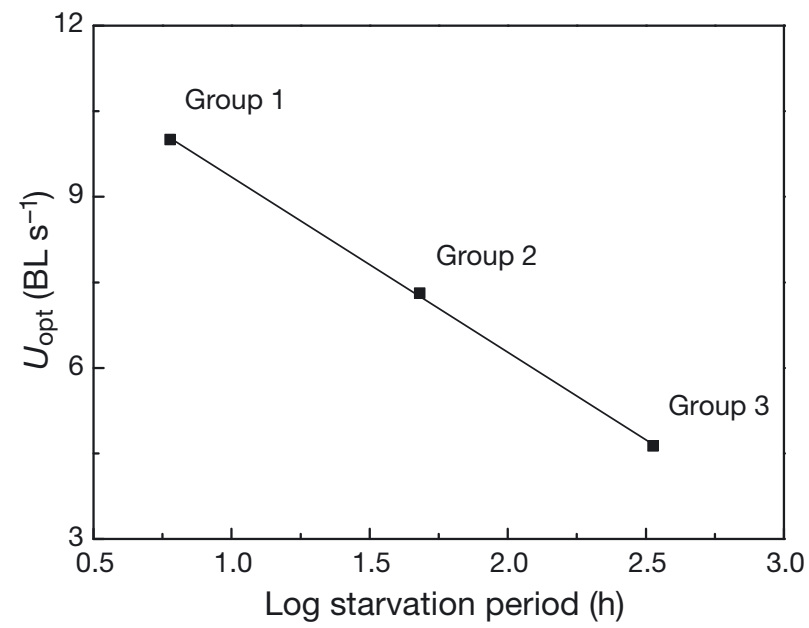

Fig. 5. Ctenopharynodon idellus. Variation of optimal swimming speed $\left(U_{\text {opti }}\right.$ body lengths $\left.[\mathrm{BL}] \mathrm{s}^{-1}\right)$ with starvation period. See Fig. 3 for details on Groups

\section{DISCUSSION}

\section{RMR, MMR and MS}

Fish metabolism is influenced by feeding (Alsop \& Wood 1997). For example, to support digestion one would expect a significant increase in oxygen consumption after feeding and a commensurate increase in RMR. For grass carp (Table 2), the RMR of Group 1, still actively digesting food, was higher than the other 2 groups. The MMR of Group 2 was significantly higher than Group 1 or Group 3. These results may be reasonable as available energy would be higher after digestion is complete and decrease with extended food deprivation. Group 2, with the lowest 
RMR and highest MMR, had a much larger MS than Group 1 or Group 3. Interestingly, digestion appears to decrease metabolic scope about as much as 2 wk of food deprivation.

\section{$U_{\text {crit }}$ and swimming efficiency}

Based on values for $U_{\text {crit, }}$ swimming capability in grass carp decreased with increase in starvation period: 9.89, 8.94 and $7.97 \mathrm{BL} \mathrm{s}^{-1}$ after $6 \mathrm{~h}, 2 \mathrm{~d}$ and $2 \mathrm{wk}$, respectively. Although the difference in $U_{\text {crit }}$ between Group 1 and Group 2 was not significant, the difference was significant between Group 1 and Group 3. The onset of anaerobic respiration occurred at higher swimming speeds with increase in starvation period (28.3, 33.6 and $40.2 \% U_{\text {crit }}$ after $6 \mathrm{~h}, 2 \mathrm{~d}$ and $2 \mathrm{wk}$, respectively), indicating that anaerobic respiration is important in the interaction between feeding and swimming.

It is reported that $U_{\text {crit }}\left(20^{\circ} \mathrm{C}\right)$ of Coreius guichenoti and Aristichthys nobilis (both Cyprinids) are 6.54 and $4.57 \mathrm{BL} \mathrm{s}^{-1}\left(20^{\circ} \mathrm{C}\right)$, respectively, after $2 \mathrm{~d}$ of starvation (Cai et al. 2012, Tu et al. 2012). $U_{\text {crit }}$ of grass carp (8.94 BL s${ }^{-1}$ ) was higher than either of these species. Comparing morphological characteristics, the body of grass carp of similar body weight is longer and thinner than those of the 2 other Cyprinids; a slender morphology produces less drag at a given countercurrent velocity (Boily \& Magnan 2002). While $U_{\text {crit }}$ is a measure of sustained maximum swimming speed as determined by an experimental protocol under controlled conditions, it correlates well with sustained maximum swimming speed under natural conditions (Cai et al. 2013). $U_{\text {crit }}$ provides reliable design criteria for the maximum velocity of water in a fish ladder slot.

The speed exponent in Eq. (2) $C_{\text {, }}$ is inversely related to swimming efficiency: it decreased slightly from Group 1 to Group 2 and then increased significantly for Group 3. Videler \& Nolet (1990) reported that $C$ is generally in the range of 1.1 to 3.0; For Groups 1, 2 and 3 of this study, $c=1.46$, 1.23 and 1.91, respectively, which are within the reported range (Table 2). Higher speed exponents are associated with lower swimming efficiency (Wardle et al. 1996). As would be expected, swimming efficiency increased after digestion was complete and decreased with extended food deprivation. Swimming efficiency is particularly important for grass carp, since many fish species eat little or nothing during migration (Larsen 1980, Hodgson \& Quinn 2002).

\section{EPOC, anaerobic swimming and $\% U_{\text {crit }}$}

EPOC is a measure of the capability to recover from fatigue and is positively related to anaerobic respiration (Lee et al. 2003b, Fu et al. 2009). It has been reported that EPOC is associated with circulating catecholamine and the gluconeogenic-glycolytic and triglyceride-fatty acid cycles (Gaesser \& Brooks 1984, Bahr 1992). EPOC of grass carp increased slightly with starvation period. Since stress increases the level of norepinephrine, a catecholamine, and food deprivation causes stress, it is likely that increased stress affects the metabolic cycles in a manner that decreases recovery capability but activates more anaerobic respiration.

Following exhaustion at the $U_{\text {crit }}$, the recovery time is $1.5 \mathrm{~h}$ in Atlantic cod Gadus morhua (Reidy et al. 1995) and about $1 \mathrm{~h}$ in sockeye Oncorhynchus nerka (Lee et al. 2003a). These values of recovery time are very similar to the values for grass carp we measured in this study. Determining recovery time is very important for setting criteria for the resting pools in fish ladders.

Jones (1982) reported that aerobic swimming in cyprinids is only sufficient to reach 30 to $50 \%$ of $U_{\text {crit }}$. However, Rome et al. (1984) used electromyography to determine that white muscle fiber begins to contribute in Cyprinus carpio (also a Cyprinid) at $80 \%$ $U_{\text {crit }}$. Results from this investigation indicate that white muscle fiber begins to contribute to swimming in grass carp at 28.31 to $40.15 \% U_{\text {crit }}$ (Fig. 2), close to the range reported by Jones (1982), but sooner than in C. carpio. White muscle fiber has higher contraction rates, but anaerobic metabolism and production of lactic acid is the cost of attaining higher speeds (Rome et al. 1990). The occurrence of anaerobic metabolism at relatively low swimming speeds in grass carp must be reflected in the resting pools of fish ladders.

It is interesting that both EPOC and $U_{a}$ varied directly with log time (h) of food deprivation (Fig. 4). The rates of increase of EPOC and $U_{a}$ with time since feeding are reported here for the first time. There are only 3 data points, but the correlation coefficients are high $\left(R^{2}=0.972\right.$ and 0.986, $\mathrm{p}=$ 0.076 and 0.053 , respectively). It is intuitive that the onset of anaerobic swimming earlier in the movement towards $U_{\text {crit }}$ would increase EPOC. However, the level of lactic acid present at exhaustion is a complicating factor and could help explain the difference in slopes. While more data is necessary for the evidence to be convincing, the 3 data points collected here do indicate a relationship between 
swimming and metabolism, and suggest a logarithmic relationship between the 2 variables and time of food deprivation.

\section{COT and $U_{\text {opt }}$}

COT was high at $1 \mathrm{BL} \mathrm{s}^{-1}$ (Fig. 3) because of the relatively large contribution made by RMR (Brill 1987). $U_{\text {opt }}$ occurs at the lowest points on the COT curve $\left(10.0,7.3\right.$ and $4.6 \mathrm{BL} \mathrm{s}^{-1}$ for $6 \mathrm{~h}, 2 \mathrm{~d}$ and $2 \mathrm{wk}$ of starvation, respectively). $U_{\text {crit }}$ also decreased with duration of food deprivation. Both feeding and food deprivation alter the metabolism of grass carp, which then affects swimming performances. When flow exceeds $U_{\text {crit, }}$ energy optimization is less important than being able to pass without fatigue (Castro-Santos 2005). Nevertheless, $U_{\text {opt }}$ can help to track fish during migration (Weihs 1973). Thus, when fish are located, $U_{\text {opt }}$ could be put into a tracking system (i.e. GPS), which would be helpful for investigating migration. However, it is difficult for researchers to know the eating time of fish, which is important for the implication of the tracking system. The speed $\left(U_{\text {opt }}\right)$ over the ground could be investigated in future. In addition, both flow velocity and direction should be studied in a laboratory and be considered in a river system.

Fig. 5 indicates an inverse relationship between $U_{\text {opt }}$ and the $\log$ of starvation period $\left(R^{2}=0.999, \mathrm{p}=\right.$ 0.012). The decrease in $U_{\text {opt }}$ with duration of food deprivation has obvious implications for grass carp because juvenile grass carp migrate to feed. Because $U_{\text {opt }}$ depends on both metabolic condition and swimming capability, this logarithmic relationship would be expected, given that EPOC and $U_{a}$ also varied with the log of starvation period. These linear relationships will clearly break down when the starvation period passes a critical point.

\section{CONCLUSION}

This study clarifies the interrelationships between feeding, food deprivation and swimming performances of grass carp, provides data on swimming speed at the onset of anaerobic metabolism, and the time to recover from fatigue. In addition, it demonstrated that feeding and food deprivation affect swimming efficiency, metabolism (aerobic and anaerobic) and swimming capability, with only slight effects on EPOC and recovery time.
Acknowledgements. We thank R. Taupier, L. Zhang and S. Tian, who also contributed to the work providing assistance with the writing. This work was supported by Major Science and Technology Program for Water Pollution Control and Treatment in the National Twelfth Five-Year Plan of China (Grant number: 2012ZX07104-002-04) and the National Nature Science Foundation of China (Grant number: 51309140).

\section{LITERATURE CITED}

Agius C, Roberts RJ (1981) Effects of starvation on the melano-macrophage centres of fish. J Fish Biol 19: 161-169

Alsop D, Wood C (1997) The interactive effects of feeding and exercise on oxygen consumption, swimming performance and protein usage in juvenile rainbow trout (Oncorhynchus mykiss). J Exp Biol 200:2337-2346

Bahr R (1992) Excess post-exercise oxygen consumption magnitude, mechanisms, and practical implications. Acta Physiol Scand 605:1-70

Bilton HT, Robins GL (1973) The effects of starvation and subsequent feeding on survival and growth of fulton channel sockeye salmon fry (Oncorhynchus nerka). J Fish Res Board Can 30:1-5

Boily P, Magnan P (2002) Relationship between individual variation in morphological characters and swimming costs in brook charr (Salvelinus fontinalis) and yellow perch (Perca flavescens). J Exp Biol 205:1031-1036

Brett JR (1964) The respiratory metabolism and swimming performance of young sockeye salmon. J Fish Res Board Can 21:1183-1226

Brill RW (1987) On the standard metabolic rates of tropical tunas, including the effect of body size and acute temperature change. Fish Bull 85:25-35

Cai L, Tu Z, Yuan X, Liu G, Liu D, Shi X, Huang Y (2012) Swimming capability and swimming behavior of juvenile Aristichthys nobilis. Resour Environ Yangtze Basin 21: 89-95 (in Chinese with English Abstract)

Cai L, Taupier R, Johnson D, Tu Z, Liu G, Huang Y (2013) Swimming capability and swimming behavior of juvenile Acipenser schrenckii. J Exp Zool A Ecol Genet Physiol 319:149-155

Castro-Santos T (2005) Optimal swim speeds for traversing velocity barriers: an analysis of volitional high-speed swimming behavior of migratory fishes. J Exp Biol 208: 421-432

Chen YJ, Tian LX, Yang HJ, Chen PF, Yuan Y, Liu YJ, Liang GY (2012) Effect of protein and starch level in practical extruded diets on growth, feed utilization, body composition, and hepatic transaminases of juvenile Grass carp, Ctenopharyngodon idella. J World Aquacult Soc 43:187-197

Cudmore B, Mandrak NE (2004) Biological synopsis of grass carp (Ctenopharyngodon idella). Can Manuscr Rep Fish Aquat Sci 2705:1-44

Fu SJ, Zeng LQ, Li XM (2009) Effect of meal size on excess post-exercise oxygen consumption in fishes with different locomotive and digestive performance. J Comp Physiol B 179:509-517

Gaesser GA, Brooks GA (1984) Metabolic bases of excess post-exercise oxygen consumption: a review. Med Sci Sports Exerc 16:29-43

> Hodgson S, Quinn TP (2002) The timing of adult sockeye 
salmon migration into fresh water: adaptions by population to prevailing thermal regimes. Can J Zool 80: 542-555

Jain KE, Hamilton JC, Farrell AP (1997) Use of a ramp velocity test to measure critical swimming speed in rainbow trout, Oncorhynchus mykiss. Comp Biochem Physiol A 117:441-444

Jones DR (1982) Anaerobic exercise in teleost fish. Can J Zool 60:1131-1134

> Koprucu K, Sertel E (2012) The effects of less-expensive plant protein sources replaced with soybean meal in the juvenile diet of grass carp (Ctenopharyngodon idella): growth, nutrient utilization and body composition. Aquacult Int 20:399-412

> Larsen LO (1980) Physiology of adult lampreys, with special regard to natural starvation, reproduction, and death after spawning. Can J Fish Aquat Sci 37:1762-1779

Lee CG, Farrell AP, Lotto A, Hinch SG, Healey MC (2003a) Excess post-exercise oxygen consumption in adult sockeye (Oncorhynchus nerka) and coho (O. kisutch) salmon following critical speed swimming. J Exp Biol 206: 3253-3260

Lee CG, Farrell AP, Lotto A, MacNutt MJ, Hinch SG, Healey MC (2003b) The effect of temperature on swimming performance and oxygen consumption in adult sockeye (Oncorhynchus nerka) and coho (O. kisutch) salmon stocks. J Exp Biol 206:3239-3251

Li KG, Cao ZD, Fu SJ (2012) Effect of feeding on excess postexercise oxygen consumption in juvenile Chinese catfish (Silurus asotus Linnaeus). Acta Hydrobiol Sin 36: 1035-1040

McKenzie DJ, Martinez RM, Morales A, Acosta J, Morales R, Taylor EW, Steffensen JF, Estrada MP (2003) Effects of growth hormone transgenesis on metabolic rate, exercise performance and hypoxia tolerance in tilapia hybrids. J Fish Biol 63:398-409

Ministry of Water Resources (2011) Statistic bulletin on China water activities. China Water Power Press, Beijing

Editorial responsibility: Christine Paetzold, Oldendorf/Luhe, Germany
Ohlberger J, Staaks G, Holker F (2007) Estimating the active metabolic rate (AMR) in fish based on tail beat frequency (TBF) and body mass. J Exp Zool A Ecol Genet Physiol 307:296-300

Reidy SP, Nelson JA, Tang Y, Kerr SR (1995) Post-exercise metabolic rate in Atlantic cod and its dependence upon the method of exhaustion. J Fish Biol 47:377-386

Rome LC, Loughna PT, Goldspink G (1984) Muscle fibre activity in carp as a function of swimming speed and muscle temperature. Am J Physiol 247:272-279

Rome LC, Funke RP, Alexander RM (1990) The influence of temperature on muscle velocity and sustained performance in swimming carp. J Exp Biol 154:163-178

> Tu Z, Yuan X, Han J, Shi X, Huang Y, Johnson D (2011) Aerobic swimming performance of juvenile Schizothorax chongi (Pisces, Cyprinidae) in the Yalong River, southwestern China. Hydrobiologia 675:119-127

Tu Z, Li L, Yuan X, Huang Y, Johnson D (2012) Aerobic swimming performance of juvenile Largemouth bronze gudgeon (Coreius guichenoti) in the Yangtze river. J Exp Zool A Ecol Genet Physiol 317:294-302

> Videler JJ, Nolet BA (1990) Cost of swimming measured at optimum speed: scaling effects, differences between swimming styles, taxonomic groups and submerged and surface swimming. Comp Biochem Physiol A 97:91-99

Wang Q, Zeng W, Liu C, Zhang C, Wang Y, Shi C, Wu S (2012) Complete genome sequence of a reovirus isolated from grass carp, indicating different genotypes of GCRV in China. J Virol 86:12466, doi:10.1128/JVI.02333-12

> Wardle CS, Soofiani NM, O'Neill FG, Glass CW, Johnstone ADF (1996) Measurements of aerobic metabolism of a school of horse mackerel at different swimming speeds. J Fish Biol 49:854-862

Weihs D (1973) Optimal fish cruising speed. Nature 245: 48-50

> Yagci O (2010) Hydraulic aspects of pool-weir fishways as ecologically friendly water structure. Ecol Eng 36: $36-46$

Submitted: June 26, 2013; Accepted: October 30, 2013

Proofs received from author(s): January 3, 2014 